\title{
National QuarkNet Program
}

\section{Cooperative Research and Development Agreement Final Report}

CRADA Number: FRA-2014-0023

\section{Fermilab Technical Contact: Marge Bardeen}

Summary Report

27 September 2019 


\section{NOTICE}

This report was prepared as an account of work sponsored by an agency of the United States government. Neither the United States government nor any agency thereof, nor any of their employees, makes any warranty, express or implied, or assumes any legal liability or responsibility for the accuracy, completeness, or usefulness of any information, apparatus, product, or process disclosed, or represents that its use would not infringe privately owned rights. Reference herein to any specific commercial product, process, or service by trade name, trademark, manufacturer, or otherwise does not necessarily constitute or imply its endorsement, recommendation, or favoring by the United States government or any agency thereof. The views and opinions of authors expressed herein do not necessarily state or reflect those of the United States government or any agency thereof.

Available electronically at http://www.osti.gov/bridge

Available for a processing fee to U.S. Department of Energy and its contractors, in paper, from:

U.S. Department of Energy Office of Scientific and Technical Information

P.O. Box 62

Oak Ridge, TN 37831-0062

phone: 865.576 .8401

fax: 865.576 .5728

email: mailto:reports@adonis.osti.gov

Available for sale to the public, in paper, from:

U.S. Department of Commerce

National Technical Information Service

5285 Port Royal Road

Springfield, VA 22161

phone: 800.553 .6847

fax: 703.605.6900

email: orders@ntis.fedworld.gov

online ordering: http://www.ntis.gov/ordering.htm 
In accordance with Requirements set forth in Article $X$ of the CRADA document, this document is the final CRADA report, including a list of Subject Inventions, to be forwarded to the Office of Science and Technical Information as part of the commitment to the public to demonstrate results of federally funded research.

CRADA number: $\quad$ FRA-2014-0023

CRADA Title: $\quad$ National QuarkNet Program

Parties to the Agreement: University of Notre Dame Du Lac and Fermi Research Alliance, LLC.

\section{Abstract of CRADA work:}

The agreement covers the joint administration of the National QuarkNet Program by Fermilab, on behalf of DOE, and Notre Dame, on behalf of the National Science Foundation. QuarkNet has established centers at universities and national laboratories conducting research in particle physics across the United States. Mentor physicists and physics teachers collaborate to bring cutting-edge physics to high school classrooms. QuarkNet offers research experiences for teachers and students, teacher workshops and sustained follow-up support. Through these activities, teachers enhance their knowledge and understanding of scientific research and transfer this experience to their classrooms, engaging students in both the substance and processes of contemporary physics research. The QuarkNet Program has been helping to improve science education in high schools across the U.S. and helping to develop America's technological workforce.

\section{Summary of Research Results:}

In addition to general administrative support provided by Fermilab and Notre Dame, the two institutions shared responsibility for annually supporting 3 staff teachers who coordinated the efforts of 52 QuarkNet Centers. The staff teachers helped establish and build the capacity of the partnership of physicists and teachers at each center. Fermilab and Notre Dame also jointly supported the Cosmic Ray e-Lab, provided Cosmic Ray Detectors to participating high schools, and annually hosted a Summer Workshop for 25 teachers. The QuarkNet program involves more than 500 high school teachers across the United States. Contributions by Fermilab and Notre Dame are typically "in-kind" and cover salary and travel for the teaching and support staff who serve the 52 QuarkNet Centers, the Cosmic Ray Detection program (detectors and computing support), the Summer Workshop/Boot Camp, and external evaluators.

\section{Related Reports, Publications, and Presentations:}

Notre Dame QuarkNet Annual Report 
Subject Inventions listing:

None

Report Date: 27 September 2019

Technical Contact at Fermilab: Marge Bardeen

This document contains NO confidential, protectable or proprietary information. 